\title{
Analysis of the Relationship between Financial Development, Employment and Institutions on Economic Growth in WAEMU Countries
}

\author{
Firmin Ayivodji \\ Ph. D. Candidate in Economics at \\ Montreal University (UdeM), Canada \\ Rémy Hounsou, Ph. D. \\ National School of Applied Economics and Management \\ (ENEAM/UAC), Benin \\ Emmanuel Tago \\ Economist Statistician Engineer, Economics and Statistics, \\ National School of Statistics and Economic Analysis (ENSAE), Senegal
}

\begin{abstract}
This study analyzes the relationship between financial development and economic growth on the one hand and the link between employment level and economic growth on the other hand in the context of financial liberalization. Also the question of the role of the institutional factors in the facilitation of the credit granting in the eight (08) countries of the WAEMU is approached. In doing so, strategies based on conventional fixed effects methods, with correction of Driscoll-Kraay (1998), Pooled Mean Group (PMG) of Pesaran et al. (1995, 1999) and spatial autoregressive models (SAC) are used to estimate the different equations over the period 1990-2015. The results suggest that financial development is positively associated with economic growth in WAEMU countries while an improvement in the level of employment stifles economic development. The results show that there is a positive and significant correlation between quality of democratic institutions and economic growth whatever the indicators of financial development considered except the money supply. The study recommends a strengthening of the financial development with a possible greater regularity.
\end{abstract}

Key words: financial development, economic growth, employment level, financial institutions, panel data, WAEMU.

JEL: 016; G21; 043; 047; C23; F62.

\section{INTRODUCTION}

Studies on the relationship between financial development and economic growth continue to interest economists both theoretically and empirically. The financial crisis of 2008 has highlighted the extent of the impact that one can have on the other. In the economic literature, many authors support the leading role of the financial system in the process of growth and development. The pioneering work of McKinnon (1973) and Shaw (1973) on financial liberalization policies remains one of the most striking facts in the literature in the sense that these authors have drawn on the economic policy recommendations made by the Bretton Woods institutions towards developing countries. In fact, McKinnon (1973), by testing the three hypotheses of the links between finance and growth proposed by Patrick (1966), leads to the conclusion that the causal link from financial development to growth is more decisive. Several other studies have confirmed this conclusion, like the work of King and Levine (1993a, 
b), Pagano (1993), Neusser and Kugler (1998), Levine et al. (2000) and Calderón and Liu (2003).

However, the results of policies based on financial liberalization are mixed, given the macroeconomic instability and subsequent financial crises. The idea that countries with a developed financial system have high growth rates has been called into question by many authors such as Robinson (1952), Dornbush and Reynoso (1989) for example. According to the first cited, the importance attached to finance tends to neglect the sense of causality between growth and finance. The mixed results of financial liberalization have led to the emergence of new streams of thought that focus on controversial results in the relationship between financial development and economic growth. These authors also show that the impact of financial development on growth varies from one country to another according to their level of development. Questions about the ability of financial reforms to promote savings and economic growth then emerged.

We ask ourselves the question of why some African countries, in particular those of WAEMU, cannot manage to ensure their financial and economic development, whereas others, like those of East Asia, succeed. In other words, how do we explain the fact that the same financial reform ends with a success in one country and a failure in another? These questions, combined with the importance of the implications of the relationship between financial development and growth in economic policy, require a better understanding of the link between these two macroeconomic variables. The purpose of this study is to empirically analyze the relationship between finance, employment and institutions and economic growth in WAEMU countries. The relationship between financial development and economic growth has attracted much interest in the economic literature. However, very few studies simultaneously took into account employment, institutions and finance in explaining economic growth, especially for the countries of sub-Saharan Africa.

To our best knowledge, only the study by Keho (2012) takes into account both institutions and finance in this relationship for WAEMU countries. Institutional variables and employment were largely ignored in explaining the macroeconomic and financial performance of these countries in general. This study thus makes an empirical contribution to economic research by assessing the extent to which the institutional environment of WAEMU countries influences the productive efficiency of the financial sector. Far from being a study of the determinants of economic growth, it contributes to the debate on the link between the financial sector and the real sector. Taking into account the institutional environment would help to better understand the rationality of banks' behavior with respect to their holding, sometimes excessive, of liquidity or, on the contrary, to their creation of money.

In addition to this empirical contribution, the study introduces two major methodological innovations. First, the study uses a relatively efficient estimation technique compared to usual panel data methods. Specifically, we use Pooled Mean Group (PMG) and Mean Group (MG) methods proposed respectively by Pesaran et al. (1999), Pesaran, and Smith (1995). The advantage of these estimation methods compared to classical methods (fixed effects, random effects or generalized moments) is to introduce heterogeneity in some coefficients to be estimated. In fact, the PMG method reconciles in the same specification the routine approach imposing fixed coefficients and that implying country-specific coefficients. Thus, we can specify that the long-term relationship between the variables is identical for all countries but that each country follows its own dynamic to converge towards this common relation. This assumption seems reasonable for WAEMU countries that share the same monetary policy and aim for the 
long-term convergence of their economies. Second, we apply the recently developed methods of exploratory spatial data analysis (Anselin et al., 1996) to refine the description of the geographic dynamics of zone growth. This allows us to shed new light on the usual measure of the causality between finance, employment, institutions and growth that could veil particular geographic patterns that fluctuate over time. This approach allows a comparative study of the results obtained before and after taking into account the spatial autocorrelation, in order to detect the impact of the spatial effects on the relation between the variables of interest.

The rest of the paper is organized as follows. In section 2, we present some background of the banking sector in the WAEMU countries. Section 3 discusses the literature review on the relations between financial development, employment, institutions and economic growth. Section 4 presents the methodology and the variables used to conduct the study. The results of the estimates are analyzed in section 5. Section 6, by concluding the study, highlights key findings and recommendations of economic policies.

\section{BACKGROUND OF THE BANKING SECTOR IN WAEMU}

The West African Economic and Monetary Union (WAEMU) brings together the former French colonies of West Africa, namely Benin, Burkina Faso, Ivory Coast, Mali, Niger, Senegal and Togo, and Guinea Bissau, which was a Portuguese colony. This Union represents part of the CFA zone, the second part being composed of the Central African countries grouped within the CAEMU that are Cameroon, the Central African Republic, Congo- Brazzaville, Gabon, Equatorial Guinea, and Chad. The analysis of the situation of the main components of the Union's financial sector, taking into account recent developments in the external and internal economic environment, draws on internationally-defined financial soundness indicators to assess the risks to which face financial institutions. Hence, for credit institutions, the indicators used are, among others, capital adequacy, portfolio quality, corporate governance, profitability, liquidity and market risks.

The analysis of the internal and external economic environment highlights vulnerabilities that could hinder the achievement of regional economic prospects and degrade the situation of banks. These are the factors relating to the socio-political crises in Ivory Coast, Guinea-Bissau and Burkina Faso combined with the difficulties of public finances, the evolution of oil prices and raw materials exported by the Member States of WAEMU and climatic hazards that may affect the results of agricultural campaigns. The banking system in the area has evolved since 2000 in an environment characterized by the slowdown in regional economic activity, due in part to the negative effects of the socio-political context in some countries of the Union.

However, banks and financial institutions have well resisted to macroeconomic shocks. In fact, according to the latest report of the WAEMU commission (2015), 137 approved credit institutions were counted including 103 banks, 19 bank branches, 11 financial institutions and 4 branches of financial institutions. Senegal and Ivory Coast together hold the largest number of banks compared to other countries and account for nearly $50 \%$ of the financial assets of the region. Nevertheless, despite the efforts made in the banking system following the reforms implemented by the Central Bank (BCEAO), much remains to be done because the ratio of the broad money supply compared to the GDP which is 32.5\% in 2015 against $22.1 \%$ on the period 2004-2008, remains below the average of low-income countries in sub-Saharan Africa. Regarding the financial soundness of the banking sector, the solvency ratio of banks was higher $(9.3 \%)$ than the required minimum (8\%), but it was lower in half of the countries (IMF, 2015). 


\section{LITERATURE REVIEW}

This section revisits the theoretical and empirical literature on the relationship between financial development, employment level, institutions, and economic growth based primarily on panel data methodology. In particular, we put into perspective the work done from samples from African countries.

\section{Financial development and growth}

Financial development is the process by which a financial system gains in depth, accessibility, efficiency and diversity. The relationship between financial development and growth has been the subject of many studies dating back to the modern history of economic thought. We propose here a synthesis of the work on financial development and economic growth, based on the panel data methodology. One of the first empirical analyzes of the relationship between growth and financial development is without doubt that of King and Levine (1993a). Based on a cross-sectional study, they lead to conclusion that financial development can predict economic growth in the next 10 to 30 years after highlighting the positive link between these two macroeconomic variables. They also find that the best indicators for measuring the level of financial development are, among others, the liquidity ratio, which measures the size of financial intermediaries through the volume of liquid liabilities relative to GDP; the ratio of bank credit granted by commercial banks to all domestic bank credit, including that of the Central Bank; the share of bank credit allocated to private enterprises in relation to all domestic credit and the share of credit granted to private firms in relation to GDP. Authors such as Roubini and Sala-i-Martin (1992), Savvides (1995) and Odedokun (1996) have also demonstrated a positive relationship between financial development and growth, and thus provide empirical validation of endogenous growth models, taking into account financial development. Levine et al. (2000) use a sample of 71 countries of all levels of development with data for the period 1960-1995 to estimate the impact of financial development on economic performance. They find a positive and significant relationship between financial development and different measures of growth measurement: the rate of economic growth, the rate of capital accumulation, and the overall productivity of factors. Their results are robust to different econometric techniques including the Generalized Moment Method in dynamic panel. However, Rousseau and Wachtel (2011) show that the positive impact of financial development on economic growth is not robust over a long period because their results reveal a positive relationship between the two variables over the period 1960-1990 and a relationship between the two variables not significant over the period 1990-2004. The main explanation for their results is that the multiple crises of the last two decades have reduced the impact of financial development on growth.

Other econometric approaches have been used by some authors to study the link between growth and financial development. This is for example the statistical analysis of causality. Hence, Spears (1992) shows that financial intermediation (measured by M2 / GDP) is a cause, in a Granger's sense, of per capita GDP growth in Cameroon, Ivory Coast, Kenya and Malawi. Burkina Faso has the distinction of presenting bidirectional causality. Venet and Raffinot (1998) focused their interest on a sample made of WAEMU countries over the period 19701995 as well as on Cameroon for the period 1963-1995. Their analysis was conducted on the one hand using panel econometrics (for WAEMU countries), and on the other hand through statistical tests of causality. Their results confirm the leading role of financial development in the growth process. 
However, another part of the literature argues that the quality of institutions can be the source of financial development and economic growth, and could explain non-linearity in the relationship between finance and growth.

\section{Role of institutions in finance and economic growth}

In the recent literature, many authors have shown that macroeconomic stability and liberalization remain sufficient to deepen the financial sectors and drive growth, and that these should accompany other institutional reforms. Examining the relationship between financial development and economic growth requires an accurate assessment of financial development. The choice of the indicator is very important in studies of the relationship between these two variables. Indicators of a financial system's ability to allocate credit, extract and use information, and exercise governance are difficult to define, and even more difficult to quantify (Beck et al., 2008).

This is why most of the empirical work that seeks to capture the relationship between finance and growth focuses on the size of the financial sector. As a result, some authors have little interest in the relationship between the two variables. According to these authors, growth and financial development come from the quality of institutions. An institution can be defined as the set of rules and norms of a society or, more formally, as the constraints established by men who regulate behaviors (North, 1990). By referring to certain indicators of the quality of institutions, some authors have succeeded in showing that an efficient institutional framework favors the most productive investments, the development of financial intermediation and, subsequently, economic growth (Keho, 2012). Thus, De Gregorio and Guidotti (1995) found a negative relationship between the ratio of bank credit to the private sector as a percentage of GDP and economic activity in a panel study of 12 countries in Latin America, and this is explained by the fact that the context was not appropriate for financial liberalization.

Levine and Renelt (1992) and Wurgler (2000) have shown that public freedoms and the protection of investor rights have positive effects on investment efficiency and economic performance. By applying the GMM method in dynamic panel, Law and Azman-Saini (2008) lead to results indicating that the quality of banking regulation is crucial for the expansion of the banking sector. Many other authors have analyzed the link between the quality of institutions and growth as well as the development of the financial system. Among others, Baltagi et al. (2009) who showed that institutions account for a large part of the variations in financial development; Law and Habibullah (2009) who also argue that the quality of institutions is an important determinant of the level of financial development.

\section{Employment and economic growth}

The literature provides important empirical work relating growth to the numbers employed.

Recent studies include Padalino and vivarrlli (1997), Pehkonen (2000), Piacentini and Pini (2000), Döpke(2001), Mourre (2004), Kapsos (2005) and Seyfried (2007) have instead studied the elasticity of employment in place of Okun's law that highlights the negative relationship between unemployment and real GDP. Kapsos (2005), while showing the instability of the indicator of Islam (2004) and Islam and Nazara (2000), proposes arc elasticity. Basing his regression on a log of GDP growth with a country as a dummy variable, he estimates the elasticity point for a single country and then he studies the elasticity by sector of activity. Padalino and Vivarelli (1997) show how the elasticity of employment relative to growth increases the fact that the current forms of technological change had weakened or limited the positive correlation between growth and employment during the golden age of Fordism. To support their idea, they empirically calculate the elasticity of employment over the period 
1960 to 1994 and choose two subgroups (1960-1973 and 1980-1994) over the Fordist and post-Fordist period, respectively. The elasticity formula, which respects the long-run relationship and the correlation of employment, and the annual GDP growth rate for the short term were used for this purpose.

Other authors have also looked at the relationship between employment and growth. Using a panel of provincial data, Surjadarma and Suryahadi (2007) find that employment growth in urban and rural areas differs according to the strategies used and that a positive impact on employment in urban areas is to be attributed to an increase in services. However, he finds that the best strategy for an increase in employment in rural area remains in the agriculture sector., Beaudry and Collard (2002) show that the effect of the negative relationship between the two variables will decrease if the domestic economy is integrated into the world economy.

\section{METHODOLOGY}

A general empirical formulation of a growth function is presented along with several empirical specifications used in the studies of those of neoclassic to authors of endogenous growth. The study follows the approach of Mankiw et al. (1992) and Law and Demetriades (2004). The starting point of our modeling is the Cobb-Douglas production function defined as follows:

$$
Y_{i t}=F\left(A_{i t}, K_{i t}, L_{i t}, H_{i t}\right)=K_{i t}^{\alpha} H_{i t}^{\beta}\left(A_{i t} L_{i t}\right)^{1-\alpha-\beta}
$$

Where $Y_{\text {it }}$ is real GDP in country $i$ in year $t$; $L_{i t}$ is the labor force; $K_{i t}$ is the stock of physical capital; $\mathrm{H}_{\mathrm{it}}$ is the stock of human capital, and $\mathrm{A}_{\mathrm{it}}$ the overall productivity of factors reflecting the level of life and the efficiency of the economy. An improvement in productivity can be obtained from a financial system and a developed institutional framework (Nelson and Sampat 2001, Benhabib and Spiegel 2000, Pagano 1993, North 1990). These two fields of analysis tend to increase the productivity of the productive sector and to improve investment productivity (Landesmann and Pagano, 1994). Thus, we posit that:

$$
L_{i t}=L_{0} e^{\left(n_{i t}\right)} \text { and } L_{i t}=A_{0} e^{\left(g t+W_{i t} \theta\right)}
$$

Where $n$ is the rate of growth of the labor force; $g$ is the rate of technical progress assumed to be constant; $w$ is the vector of financial and political development of the institutions and other factors affecting the economic efficiency of the economy; $\theta$ is the vector of coefficients that link these policies to other variables. However, the evolution or dynamics of the economy is determined by:

$$
\dot{K}_{t}=\frac{d K_{t}}{d t}=s_{k} Y_{t}-\delta . K_{t} \text { and } \dot{H}_{t}=\frac{d H_{t}}{d t}=s_{h} Y_{t}-\delta . H_{t}
$$

With, $s_{k}$ and $s_{h}$, respectively the rate of investment in physical capital and the rate of investment in human capital.

We assume that: $\mathrm{K}_{\mathrm{t}}=\mathrm{I}_{\mathrm{t}^{-}} \delta . \mathrm{K}_{\mathrm{t}}$ and $\mathrm{I}_{\mathrm{t}}=\mathrm{S}_{\mathrm{t}}$ with $\delta$ the rate of depreciation of physical capital. The other information that emerges from this capital dynamic is that gross investment $I_{t}$ is a proportion of the product. This design partly matches that of the Solow-Swan model. In addition, equality $I_{t}=S_{t}$ reflects the idea that savings can only be used for the purchase of capital goods.

Any calculation done, we find:

$$
\dot{\boldsymbol{k}}_{\boldsymbol{t}}=\boldsymbol{s}_{\boldsymbol{k}} \boldsymbol{y}_{\boldsymbol{t}}-(\boldsymbol{\delta}+\boldsymbol{g}+\boldsymbol{n}) \cdot \boldsymbol{k}_{\boldsymbol{t}}
$$




$$
\dot{h}_{t}=s_{h} y_{t}-(\delta+g+n) \cdot h_{t}
$$

Knowing that gross domestic product per effective work unit is written as:

$$
y_{t}=\frac{Y_{t}}{A_{t} L_{t}}={k_{t}}^{\alpha} \cdot h_{t}^{\beta}
$$

And substituting (6) in (4) and (5), we obtain:

$$
\begin{aligned}
& \dot{\boldsymbol{k}_{t}}=\boldsymbol{s}_{\boldsymbol{k}} \boldsymbol{k}_{t}{ }^{\alpha} \cdot \boldsymbol{h}_{t}{ }^{\beta}-(\delta+\boldsymbol{g}+\boldsymbol{n}) \cdot \boldsymbol{k}_{t}(7) \\
& \dot{\boldsymbol{h}_{t}}=\boldsymbol{s}_{\boldsymbol{h}} \boldsymbol{k}_{t}{ }^{\alpha} \cdot \boldsymbol{h}_{t}{ }^{\beta}-(\delta+\boldsymbol{g}+\boldsymbol{n}) \cdot \boldsymbol{h}_{t}(8)
\end{aligned}
$$

At equilibrium we have: $\dot{\boldsymbol{k}}_{\boldsymbol{t}}=\dot{\boldsymbol{h}}_{\boldsymbol{t}}=0$, which implies that:

$$
\begin{gathered}
\boldsymbol{s}_{\boldsymbol{k}} \boldsymbol{k}_{t}^{\alpha} \cdot \boldsymbol{h}_{t}^{\beta}=(\boldsymbol{\delta}+\boldsymbol{g}+\boldsymbol{n}) \cdot \boldsymbol{k}_{t} \\
\dot{\boldsymbol{h}_{t}}=s_{h} \boldsymbol{k}_{t}^{\alpha} \cdot \boldsymbol{h}_{t}^{\beta}=(\delta+g+n) \cdot \boldsymbol{h}_{t}
\end{gathered}
$$

Any calculation done, the equilibrium product is given by:

$$
y^{*}=A_{0} e^{W \theta}\left[\frac{s_{k}{ }^{1-\beta s_{h}}{ }^{\beta}}{\delta+g+n}\right]^{\frac{\alpha}{1-\alpha-\beta}} \cdot\left[\frac{S_{h}^{1-\alpha s_{k}}{ }^{\alpha}}{\delta+g+n}\right]^{\frac{\beta}{1-\alpha-\beta}}
$$

Econometrically, after logarithmic transformation and adding temporal and individual indices and institutional variables, the model to estimate is written as:

$$
l G D P_{i t}=\beta_{0}+\beta_{1} l F D I_{i t}+\beta_{2} l P O P_{i t}+\beta_{3} l E D U_{i t}+\beta_{4} l T R A_{i t}+\beta_{5} D E M_{i t}+\beta_{6} Q D I_{i t}+\mu_{i t}+\varepsilon_{i t}
$$

This equation is an extension of the Mankiw, et al. (1992) on panel data. The IGDP variable represents the log of real GDP in each of the countries in the sample. The explanatory variables used are: (a): IFDI is the logarithm of the financial development indicator. The study considers credit to the private sector as a percentage of GDP $(1 C)$, deposits in the banking system as a percentage of GDP $(I D)$, and money supply as a percentage of GDP $\left(I M_{2}\right)$ as an indicator of financial development; (b): IPOP is the logarithm of the ratio of the labor force to the workingage population; (c): $I E D U$, is the stock of human capital measured by the logarithm of the average number of years of schooling attained. This variable expresses a qualitative dimension of schooling, and reflects national disparities in education. Rebelo (1991) introduces into his model the human capital that he designates as all the formations, the knowledge and the good health of the worker that makes him more productive. Lucas (1988) finds that this human capital produces positive externalities; (d): Like Berthelemy and Varoudakis (1995), the variable ITRA measures the logarithm of the trade opening coefficient that we calculate by making the ratio (exports + imports) / GDP. However, this indicator is not optimal since, beyond any economic policy guidelines, it reflects the influence of natural differences such as the size and geographical location of each country. Hence, we need to search for a spatial specification in our models. Franckel and Romer (1996) and Franckel et al. (1996) have shown that trade openness has a significant and positive impact on economic growth. Finally, two other variables of democracy are also introduced into the model. This is the index of democracy $(D E M)$ and the quality of democratic institutions $(Q D I)$. Kormendi and Meguire (1985), Savvides (1995) and Fosu (2012) all show that strong democratic institutions are directly linked to a high quality of governance and that there is a strong link between democracy and economic growth. From the point of view of macroeconomic theory, the 
expected signs of all the coefficients are positive except for the signs of the coefficients $\beta_{5}$ and $\beta_{6}$ which can be positive or negative.

The beginning of the period (1990) indicates the beginning of the democratic experience for the WAEMU countries. The end of the study period (2015) is justified by the availability of recent data. The data are from most databases from the World Bank (WB), the Central Bank of West African States (BCEAO) and Freedom House.

\section{Methodological approach}

The analysis focuses on the 08 countries in the WAEMU zone because countries may have individual unobservable specificities that are not taken into account in aggregate data. The double dimension offered by panel data is an interesting asset compared to other types of data, time series and cross-sections. This double dimension makes it possible to simultaneously report on the dynamics of behaviors and their possible heterogeneity (Pirotte 2011, Sevestre 2002). The advantage of this approach lies in the presence of asymptotic good properties (unbiased estimator, convergent, etc.) that it can guarantee because of the combination of the individual and temporal dimension.

Firstly, we carried out the homogeneity tests of Hsiao (1986). The results indicate a total heterogeneity of the panel. Failure to take this heterogeneity into account may bias the conclusions of the standard estimators. However, in order to replicate conventional panel data approaches, the study proposed to do the specification tests of Hausman (1978), Wooldridge (2002) and Hoechle (2007) to discriminate between the fixed effects model and the random effects model. It should be noted that the modified Hausman (1978) tests proposed by Wooldridge (2002) and Hoechle (2007) are more robust than the standard Hausman test in the case where the assumptions that $\mu_{\mathrm{it}}$ and $\varepsilon_{\mathrm{it}}$ are iid have little chances to be performed in practice. The existence of spatial dependence in cross-section can also bias the Hausman statistic. Model specification test results (12) revealed the predominance of the fixed effects model over the random effects model. Moreover, the violation of autocorrelation hypotheses, heteroscedasticity, and the existence of a spatial dependence in the data leads us to estimate the fixed effects model with correction of Driscoll-Kraay (1998).

Secondly, since in our study the temporal dimension $(T=26)$ is more important than the individual dimension $(\mathrm{N}=8)$, we are in the presence of a macro panel (Hsiao, 2014, Pesaran, et al., 2008, Eberhardt, 2012, Pirotte, 2011, Baltagi, 2008, Hurlin and Mignon, 2005). The study of the unit root then becomes important. Our study uses panel-based first- and second-generation unit root tests (see Baltagi, 2008, Hurlin and Mignon, 2005). The first generation is characterized by the fact that inter-individual dependencies are not taken into account, which on panel data constitutes a strong hypothesis. On the other hand, the second generation lifts this assumption by considering inter individual correlations. To test the spatial dependence before the implementation of second-generation tests, we use the spatial dependence tests of Pesaran (2004), Pesaran et al. (2008) and Breusch-Pagan (1980). The Pedroni cointegration tests $(1999,2001,2004)$ carried out indicate a presence of cointegration.

\section{Estimation of the cointegration vector on Panel data}

Pedroni (2001), Kao and Chiang (2000) and Pesaran, et al. (1999) highlight the problems of convergence and the effectiveness of the OLS estimator for estimating the cointegration vector. They show that to estimate it correctly, and apply the cointegration tests appropriately, it is necessary to use specific estimation methods. Three approaches are generally used: (1) the Fully Modified Ordinary Least Squares (FMOLS) method; (2) the method of Panel Dynamic 
Ordinary Least Squares (PDOLS) and (3) the family of the Mean Group (Pooled Mean Group (PMG), Mean Group (MG), and Dynamic Fixed Effect (DFE)). Estimators of the Mean Group family are obtained by Maximum Likelihood (ML) while the FMOLS estimators and PDOLS are based on modified ordinary least squares. The main constraint of these two last methods is that the panel must be homogeneous and the variables must be integrated of the same order. This is not verified in our study, in that the variables are I (0) or I (1). In addition, the panel is heterogeneous (see Hsiao test, 1986). Until recently, the panel data estimation methods (estimators fixed effects / random or GMM) imposed homogeneity coefficients except for the constant that is assumed to capture specific effects. These approaches are criticizable. Indeed, if a variable has a positive effect in a country of sub-sample and a negative effect in the other sub-sample forcing a single coefficient for all panels could give a non-significant coefficient (Keho, 2012). It is reasonable to think that the effect of financial development on activity may differ across countries due to institutional differences and level of employment. In this case, the estimation of a single coefficient for each explanatory variable will be affected by a serious bias of heterogeneity (Pesaran and Smith, 1995).

According to Pesaran et al. (1999), autoregressive distributed lag models (ARDL) are of the form:

$$
y_{i t}=\sum_{j=1}^{p} \lambda_{i j} y_{i, t-j}+\sum_{j=0}^{q} \delta_{i j}^{\prime} x_{i, t-j}+\xi_{i}+\varepsilon_{i t}
$$

Where $x_{\mathrm{it}}$ is the vector of the explanatory variables and $\xi_{\mathrm{i}}$ is the country's fixed effect.

If the variables are cointegrated, then the error term $\varepsilon_{i t}$ is a stationary process. In this case, the model (13) can be respecified in the form of an error-correction model in which the short-term dynamics is influenced by the deviation from the long-term relationship. That is:

$$
\Delta y_{i t}=\phi_{i}\left(y_{i t-1}-\theta^{\prime}{ }_{i} x_{i t}\right)+\sum_{j=1}^{p-1} \lambda_{i j}{ }^{*} y_{i, t-j}+\sum_{j=0}^{q-1} \delta^{* \prime}{ }_{i j} x_{i, t-j}+\xi_{i}+\varepsilon_{i t}
$$

Where $\theta_{\mathrm{i}}$ is the vector of the long-term coefficients and $\Delta$ is the operator of variation between two successive dates. The adjustment coefficient $\varphi_{\mathrm{i}}$, as well as the long-term coefficients $\theta_{\mathrm{i}}$ constitute the parameters of interest. It is expected that $\varphi_{\mathrm{i}}<0$. One of the advantages of the ARDL models is that the short and long term multipliers are estimated jointly. In addition, these models allow the presence of variables that can be integrated of different orders, either I (0) or I (1), or cointegrated (Pesaran et al. 1999).

The PMG estimator allows the short-run coefficients and the adjustment coefficient to vary across countries, but the long-run coefficients are identical for all countries $\left(\theta_{i}=\theta\right)$. It has been shown that the imposition of an identical coefficient for the recall force could lead to bias (Kiviet, 1995 cited by Keho, 2012). Regarding the MG estimator, it allows heterogeneity in both short-term and long-term coefficients. Alternatively, the dynamic fixed effects model (DFE) estimator considers that the parameters are identical between individuals and is suitable for panels with little time dimension. The PMG estimator uses the maximum likelihood method. At the panel level, we have:

$$
\widehat{\phi}_{P M G}=\frac{\sum_{i=1}^{N} \widehat{\phi}_{l}}{N}, \quad \hat{\lambda}_{j, P M G}^{*}=\frac{\sum_{i=1}^{N} \hat{\lambda}_{i, j}^{*}}{N}, \widehat{\delta}_{j, P M G}^{*^{\prime}}=\frac{\sum_{i=1}^{N} \widehat{\delta}_{i j}^{*^{\prime}}}{N}, \widehat{\theta}_{P M G}=\theta
$$

The MG estimator estimates the equation for each country in the sample and then calculates the unweighted averages of the coefficients across the panel: 


$$
\widehat{\phi}_{M G}=\frac{\sum_{i=1}^{N} \widetilde{\phi}_{i}}{N}, \quad \hat{\lambda}_{j, M G}^{*}=\frac{\sum_{i=1}^{N} \tilde{\lambda}_{i, j}^{*}}{N}, \widehat{\delta}_{j, M G}^{*^{\prime}}=\frac{\sum_{i=1}^{N} \widehat{\delta}_{i j}^{* \prime}}{N}, \widehat{\boldsymbol{\theta}}_{M G}=\frac{\sum_{i=1}^{N} \widetilde{\theta}_{i}}{N}
$$

If the restriction $\theta_{i}=\theta$ is relevant, the PMG estimator is convergent and more efficient than the MG estimator (Pesaran et al., 1999). In addition, it has the advantage over the MG estimator of having good properties even when the size $\mathrm{N}$ of the sample is small relative to the time dimension (Hsiao et al., 1999). The hypothesis of long-term coefficients cannot be posited, $a$ priori, it must be tested empirically. For this, we use a Hausman-type test applied to the difference between the MG and PMG estimators. Under the null hypothesis, this difference is not significant and the PMG estimator is then preferable

\section{Estimation of the autoregressive spatial model}

This part places special emphasis on spatial panels. It should be noted that the models presented above do not explicitly take into account the existence of a possible spatial correlation between countries, which can implicitly exist. There is a question about the consequences of the negligence of such spatial interdependencies. Baltagi and Pirotte (2010) show that the effects of not taking into account the spatial dimension, if it is relevant to explain the economic phenomenon of interest, are considerable on the quality of the statistical inference, which can lead to misleading results. Elhorst $(2001,2003,2014)$, Anselin, et al. (2008) point out that the introduction of the spatial dimension has become in recent years an important research focus on Panel data. Hence, and according to Anselin and Bera (1998), the spatial dimension aims to capture two effects, namely spatial autocorrelation, which refers to the lack of independence between geographical observations and the spatial heterogeneity of variables and behaviors in space. Different specifications can be envisaged in this context. The choice of one of these depends on the context and complexity of the phenomenon to be studied. Some growth studies using panel data are not often interested in spatial correlation (Abdouni and Hanchane, 2003). But the observation of international data on growth shows that there is a certain tendency for the wealthiest nations to regroup geographically and that the same is true for poor countries (Ertur and Thiaw, 2005). Spatial models have been highlighted in growth models by Ertur and Koch (2007), Le Gallo et al. (2005), Conley and Ligon (2002), Fingleton (1999), Easterly and Levine (1998), Moreno and Trehan (1997). Our reference model, developed by $\mathrm{Yu}$ et al. (2008), combines a spatial autoregressive model with spatially autocorrelated perturbations $(1,1)$, called SARAR $(1,1)$ or SAC (Spatial Autoregressive Model), in a fixed effects spatial panel dataset:

$$
\begin{aligned}
y_{i t} & =\rho W y_{i t}+x_{i t} \beta+\mu_{i}+v_{i t} \\
v_{i t} & =\lambda M v_{i t}+\xi_{i t} \quad \mathrm{t}=1,2, \ldots, \mathrm{T} .
\end{aligned}
$$

$y_{\text {it }}$ represents the dependent variable (logarithm of GDP), $x_{\text {it }}$ the variable vector, $W$ and $M$ the weight matrices. In the case of this study, $W=M$, and denotes the $N * N$ format contiguity matrix which reflects the geographical proximity between the countries of the common borders. The intersection between a row and a column of this spatial matrix takes 0 or 1 depending on whether two countries share a border. Two main approaches have been suggested in the literature to estimate models that include spatial interaction effects. One is based on the principle of maximum likelihood (ML) and the other on instrumental variables or the generalized method of moments (IV / GMM). 


\section{Descriptive analysis}

\section{RESULTS AND DISCUSSIONS}

This section places special emphasis on the descriptive analysis of model variables. We note an average $\log G D P$ and private sector credit larger than the average of other variables (see Table 1). It should be noted that among the three financial development indicators considered, only the credit to the private sector presents an average higher than the sum of the deposit averages in the banking system and the money supply within the WAEMU zone. The fact that credit to the private sector is more important than deposits of savers may be due to the use of secondtier or commercial banks at the Central Bank (BCEAO) in the event of cash flow problems because banks are less developed in the Union. However, the disparity in the provision of credit to the private sector is strong because private credit also has the largest dispersion (high standard deviation) among the selected financial development indicators. The WAEMU zone seems to present on the basis of the averages of the characteristics of the democratic institutions a democratic stability. However, there are some disparities within countries in terms of democratic institutions. This is reflected by the strong standard deviation values observed in Table 1. The index of democracy (DEM) ranges from $(-10)$ for the least democratic regimes to $(+10)$ for the most democratic regimes. $(Q D I)$ is a variable measuring the quality of democratic institutions whose index value is between $(-10)$ and $(+10)$ : the higher the index (when it is positive), the higher the democratic institutions which are of good quality. None of the Union's countries achieves the maximum values for these two indicators.

Table 1: Statistical summary of the variables within the WAEMU zone

\begin{tabular}{llllll} 
Variables & Obs & Mean & Std. Dev. & Min & Max \\
\hline lGDP & 208 & 7.67 & 0.98 & 4.65 & 9.66 \\
lC & 208 & 12.38 & 1.62 & 7.72 & 15.31 \\
lM$_{2}$ & 208 & 3.23 & 0.38 & 1.86 & 4.04 \\
lD & 208 & 2.76 & 0.5 & 0.7 & 3.7 \\
IPOP & 208 & 4.27 & 0.13 & 3.94 & 4.44 \\
lEDU & 208 & 1.21 & 0.36 & 0.53 & 1.84 \\
lTRA & 208 & 4.07 & 0.29 & 3.38 & 4.84 \\
DEM & 208 & 3.82 & 3.00 & 0.00 & 8.00 \\
QDI & 208 & 2.03 & 4.78 & -8.00 & 8.00 \\
\hline
\end{tabular}

Source: BCEAO (2016), WDI (2016) \& Freedom House (2016), authors' work.

Figure 1 shows the evolution of the logarithm of GDP in the countries of the Union. It should be emphasized that the evolution is similar for all countries only from the 2000s. However, Ivory Coast and Senegal have the highest values for this indicator. This result reflects their strategic position in the zone. In addition, Figure 2 shows the presence of possible heterogeneity between countries in terms of production. This heterogeneity is much more pronounced for some countries in the zone. This result can be explained by the diversity of the economies with respect to fiscal policy. 


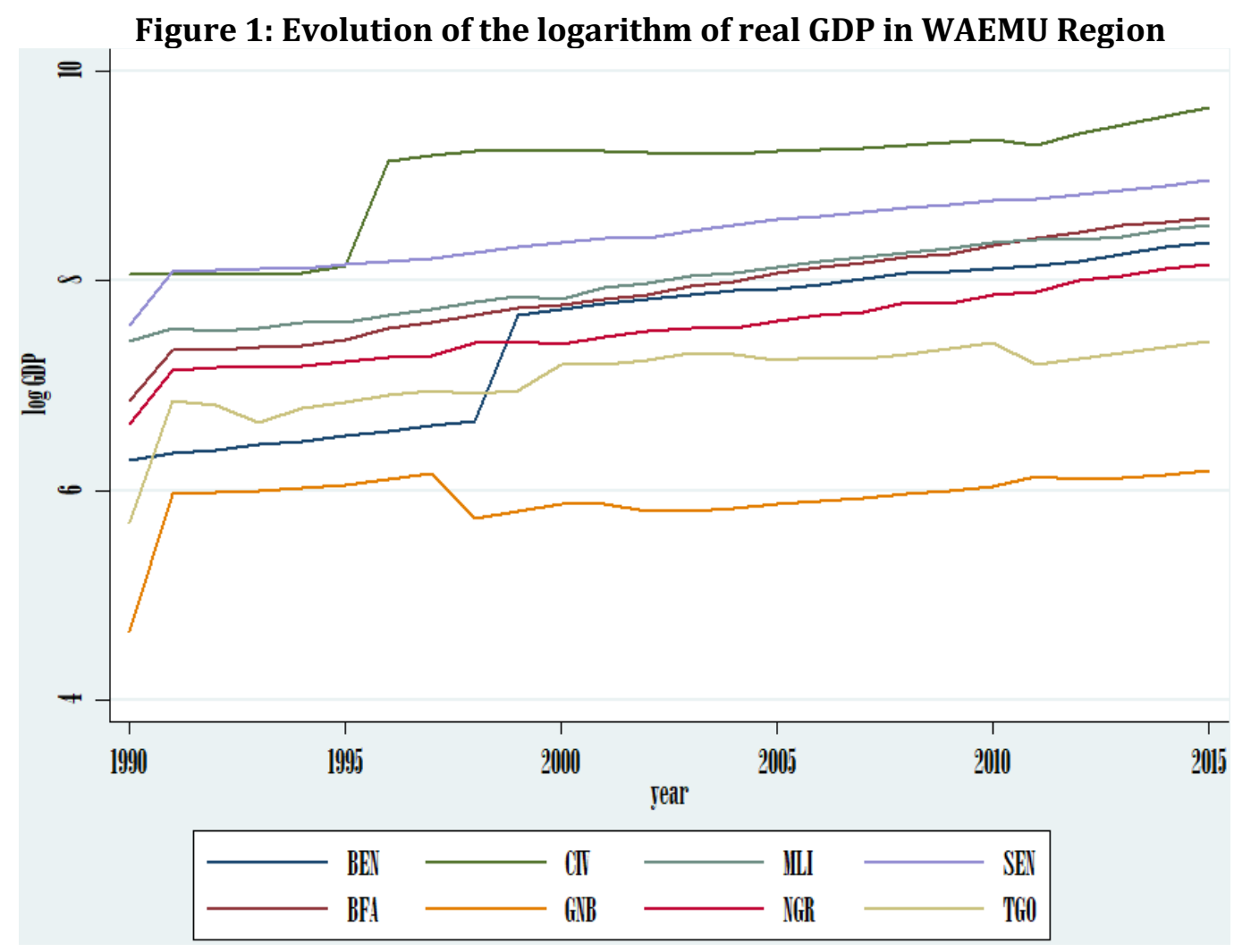

Source: BCEAO (2016), WDI (2016) \& Freedom House (2016), authors' work.

Figure 2: Heterogeneity of real GDP

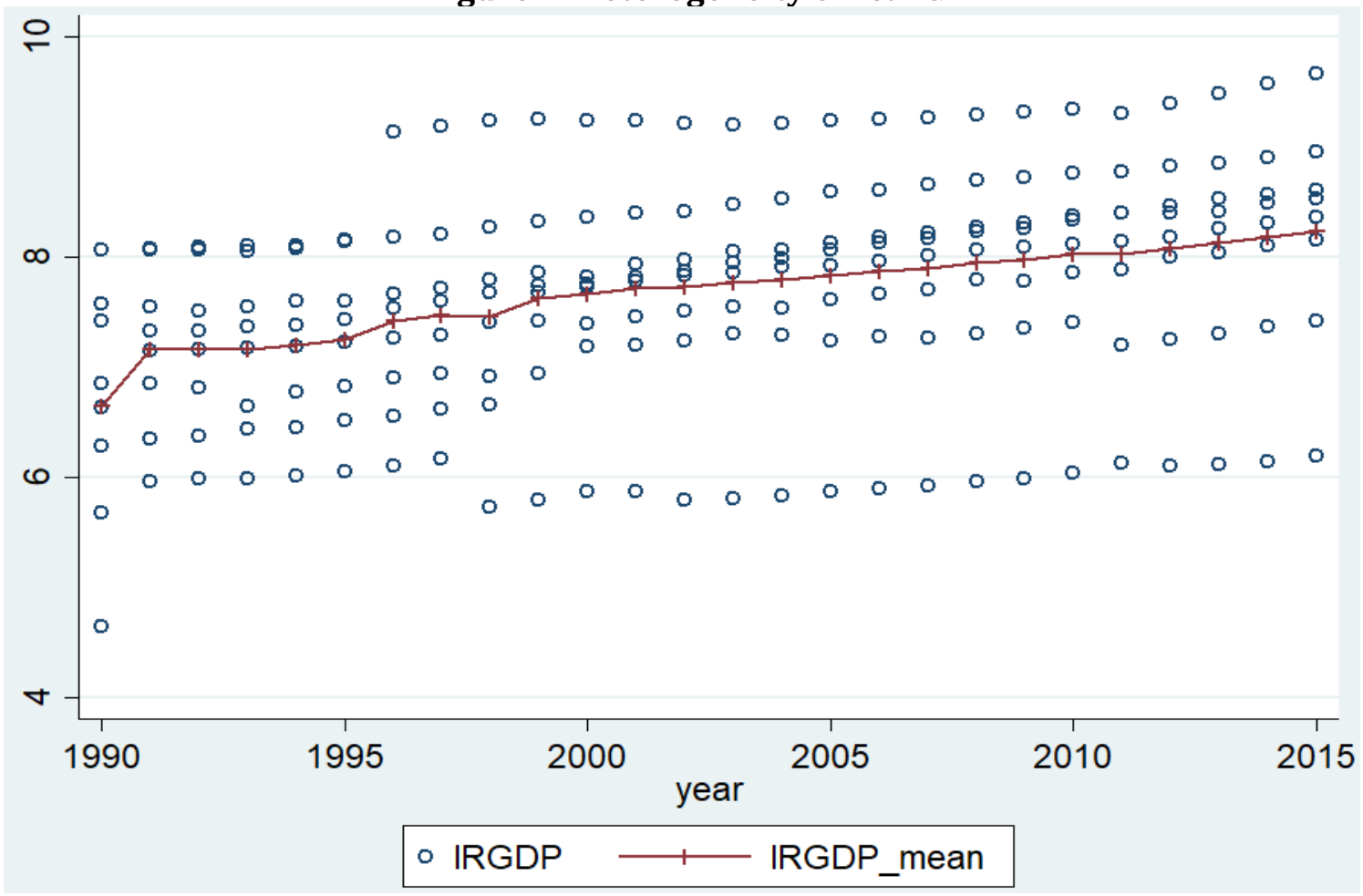

Source: BCEAO (2016), WDI (2016) \& Freedom House (2016), authors' work.

\section{Analysis of the results of the estimates}

Like the work of Acclassato and Eggoh (2012), Keho (2012) and Yahyaoui and Rahmani (2009), the results of the impact of financial development, the level of employment on economic growth in the WAEMU zone depend on the indicator in question. However, the labor 
force and the democracy Index have a negative influence on economic growth in the Union, while the average level of years of schooling attained, the rate of trade openness, the quality of institutions are positively correlated with economic growth. . In this section, we present the results using the classical panel data approach and recent developments (Pooled Mean Group and SARAR).

\section{Classical Models: Fixed Effects with Driscoll-Kraay Correction (1998)}

Table 2 presents the results of the fixed effects models with Driscoll-Kraay (1998). In this table, only credit to the private sector and deposits as indicators of financial development have a significant and positive impact on economic growth. Money supply has no influence on economic growth in WAEMU member countries. This result seems surprising, especially as the forecast of the money supply in the Union is based on the expected economic growth rate. However, the result can be attributed to the estimation problems because the estimated models assume homogeneity of the slopes of the regression. Moreover, the level of employment is negatively correlated with economic growth, thus verifying Okun's law. The average level of years of schooling attained and the quality of institutions are positively correlated with economic growth. The democracy index appears to be negatively affecting economic growth in the Union. It should be emphasized that the quality of the various estimated equations seems to be stable and is around $70 \%$ for the three financial development indicators considered. This result may confirm the relevance of the indicators selected to capture the development of the financial system in the WAEMU zone.

Table 2: Results of the Classical Fixed Effects Model with Driscoll-Kraay Correction

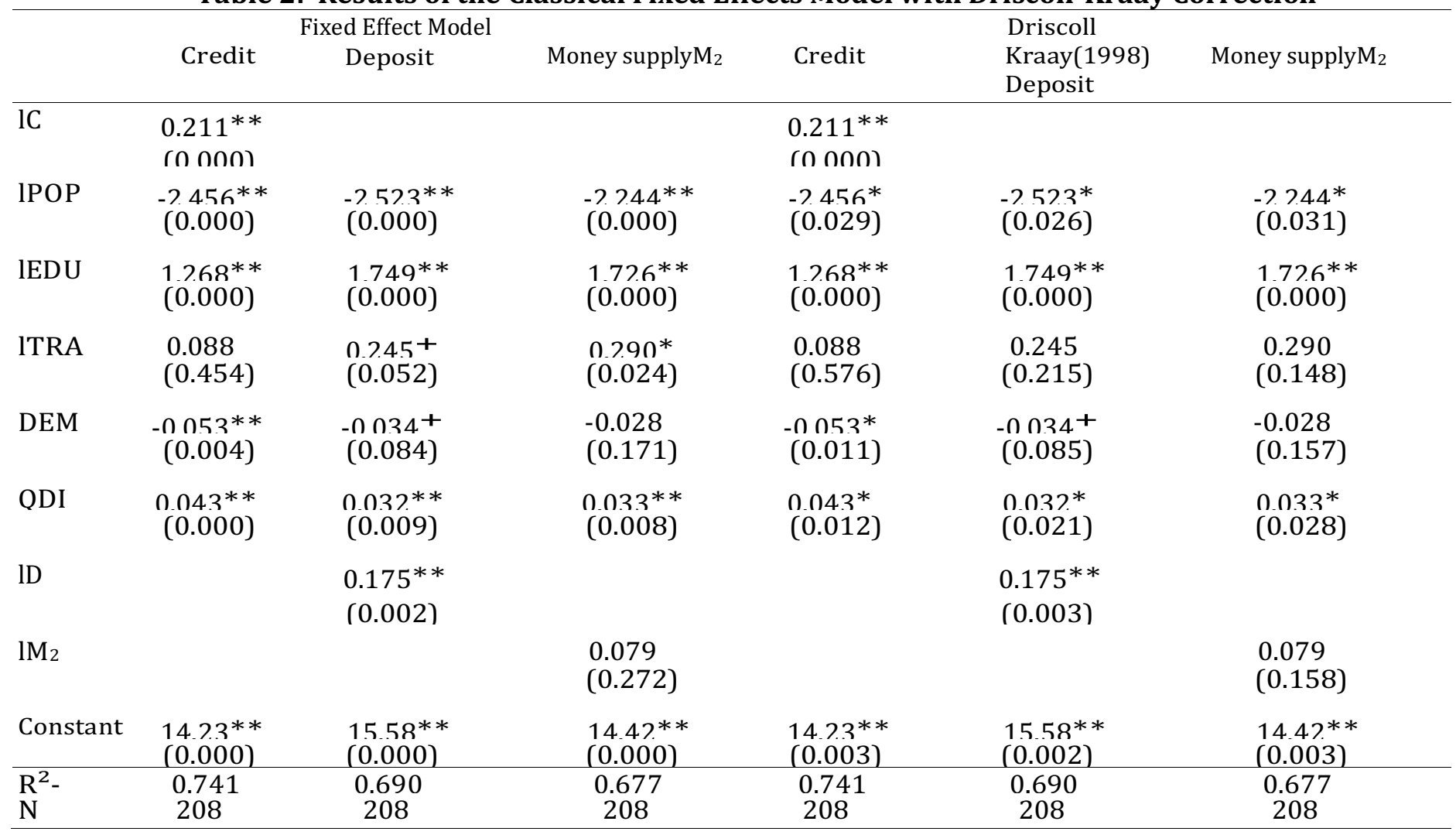

$p$-values in parentheses

$+\mathrm{p}<0.1, * \mathrm{p}<0.05, * * \mathrm{p}<0.01$

Source: BCEAO (2016), WDI (2016) \& Freedom House (2016), authors' work.

\section{Pooled Mean Group (PMG): cointegration on panel data (ARDL approach)}

We use the PMG and MG estimators to estimate long-term relationships within an errorcorrection model. Table 3 presents the results of the growth equation estimates for each of the 
selected indicators. The Hausman test shows that the assumption of homogeneity of the longterm coefficients cannot be rejected whatever the indicator of the financial development considered. The interpretation of the results is concerned with those of the PMG method. In addition, these models are statistically valid because the restoring forces are significantly negative. The results of the estimates show a positive and significant coefficient for the private sector and deposits in the banking system in the long run. The level of employment and the quality of institutions are negatively correlated with economic growth in the long-term dynamics. Similarly, the quality of institutions and the democracy index are significantly correlated with the short-term economic growth of the financial development equation. However, no indicator of financial development influences economic growth in the short-run dynamics. One of the surprising results is that the democracy index is negatively and significantly correlated to economic growth in the short-term equation and positively correlated to the short-term equation in the error-correction equation whatever the indicator. On the other hand, the quality of democratic institutions positively and significantly impacts dynamic growth in the long run. 
Table 3: Results of the cointegration model with heterogeneity: Pooled Mean Group (PMG)

Pooled Mean Group (PMG)

\begin{tabular}{|c|c|c|c|}
\hline & Private credit & Deposit & Money supply $\mathrm{M}_{2}$ \\
\hline IC & $\begin{array}{l}0.244^{* *} \\
(0.000)\end{array}$ & & \\
\hline IPOP & $\begin{array}{l}-1.026 \\
(0.140)\end{array}$ & $\begin{array}{l}0.160 \\
(0.834)\end{array}$ & $\begin{array}{l}-4.803^{* *} \\
(0.000)\end{array}$ \\
\hline IEDU & $\begin{array}{l}0.995^{* *} \\
(0.000)\end{array}$ & $\begin{array}{l}1.303^{* *} \\
(0.000)\end{array}$ & $\begin{array}{l}1.807^{* *} \\
(0.000)\end{array}$ \\
\hline ITRA & $\begin{array}{l}0.134^{* *} \\
(0.007)\end{array}$ & $\begin{array}{l}0.233^{* *} \\
(0.000)\end{array}$ & $\begin{array}{l}0.169^{+} \\
(0.061)\end{array}$ \\
\hline DEM & $\begin{array}{l}0.107^{* *} \\
(0.000)\end{array}$ & $\begin{array}{l}0.074^{* *} \\
(0.001)\end{array}$ & $\begin{array}{l}-0.010 \\
(0.460)\end{array}$ \\
\hline QDI & $\begin{array}{l}-0.071^{* *} \\
(0.000)\end{array}$ & $\begin{array}{l}-0.051^{* *} \\
(0.001)\end{array}$ & $\begin{array}{l}0.008 \\
(0.273)\end{array}$ \\
\hline ID & & $\begin{array}{l}0.399^{* *} \\
(0.000)\end{array}$ & \\
\hline $\mathrm{lM}_{2}$ & & & $\begin{array}{l}0.040 \\
(0.243)\end{array}$ \\
\hline \multicolumn{4}{|l|}{ SR } \\
\hline Error coef & $\begin{array}{l}-0.429^{* *} \\
(0.000)\end{array}$ & $\begin{array}{l}-0.417^{* *} \\
(0.001)\end{array}$ & $\begin{array}{l}-0.481^{* *} \\
(0.001)\end{array}$ \\
\hline D.lC & $\begin{array}{l}0.021 \\
(0.807)\end{array}$ & & \\
\hline D.IPOP & $\begin{array}{l}-3.586 \\
(0.682)\end{array}$ & $\begin{array}{l}-7.419 \\
(0.457)\end{array}$ & $\begin{array}{l}-13.97^{*} \\
(0.031)\end{array}$ \\
\hline D.lEDU & $\begin{array}{l}-0.485 \\
(0.475)\end{array}$ & $\begin{array}{l}-0.246 \\
(0.854)\end{array}$ & $\begin{array}{l}-0.751 \\
(0.106)\end{array}$ \\
\hline D.ITRA & $\begin{array}{l}-0.054 \\
(0.545)\end{array}$ & $\begin{array}{l}-0.123 \\
(0.233)\end{array}$ & $\begin{array}{l}-0.173^{*} \\
(0.014)\end{array}$ \\
\hline D.DEM & $\begin{array}{l}-0.065^{*} \\
(0.011)\end{array}$ & $\begin{array}{l}-0.083^{*} \\
(0.041)\end{array}$ & $\begin{array}{l}-0.054^{*} \\
(0.034)\end{array}$ \\
\hline D.QDI & $\begin{array}{l}0.038^{* *} \\
(0.003)\end{array}$ & $\begin{array}{l}0.029+ \\
(0.057)\end{array}$ & $\begin{array}{l}0.030^{+} \\
(0.062)\end{array}$ \\
\hline D.ID & & $\begin{array}{l}-0.044 \\
(0.682)\end{array}$ & \\
\hline $\mathrm{D} \mathrm{IM}_{2}$ & & & $\begin{array}{l}0.077 \\
(0.520)\end{array}$ \\
\hline Constant & $\begin{array}{l}3.074^{* *} \\
(0.000)\end{array}$ & $\begin{array}{l}1.378^{* *} \\
(0.001)\end{array}$ & $\begin{array}{l}12.19^{* *} \\
(0.000)\end{array}$ \\
\hline$N$ & 200 & 200 & 200 \\
\hline
\end{tabular}

$p$-values in parentheses

$p<0.1, p<0.05, \cdots p 0.01$

Source: BCEAO (2016), WDI (2016) \& Freedom House (2016), authors' work.

\section{Spatial Template AutoRegressive on Panel Data}

Table 4 presents the results of the autoregressive spatial model. It is apparent from this table the significance of the spatial coefficient. This shows the interest of taking into account the spatial dimension. It should be noted that financial development is positively correlated with economic growth regardless of the indicator considered. On the other hand, the level of employment has a negative influence on economic growth in the WAEMU zone. The rate of trade openness, the quality of institutions and the average level of years of schooling achieved have a positive impact on economic growth in the Union. Diffusion of the impact of financial development on growth also involves residues. 
Table 4: Results of the Spatial AutoRegressive Model

\begin{tabular}{|c|c|c|c|}
\hline & \multicolumn{3}{|c|}{ Spatial AutoRegressif (SAC) model } \\
\hline & Private credit & Deposit & Money supply $\mathrm{M}_{2}$ \\
\hline \multicolumn{4}{|l|}{ Main } \\
\hline lC & $\begin{array}{l}0.131^{* *} \\
(0.000)\end{array}$ & & \\
\hline IPOP & $\begin{array}{l}-2.681^{* *} \\
(0.000)\end{array}$ & $\begin{array}{l}-2.801^{* *} \\
(0.000)\end{array}$ & $\begin{array}{l}-2.510^{* *} \\
0.000)\end{array}$ \\
\hline IEDU & $\begin{array}{l}1.012^{* *} \\
(0.000)\end{array}$ & $\begin{array}{l}1.238^{* *} \\
(0.000)\end{array}$ & $\begin{array}{l}1.205^{* *} \\
(0.000)\end{array}$ \\
\hline ITRA & $\begin{array}{l}0.055^{+} \\
(0.582)\end{array}$ & $\begin{array}{l}0.010^{+} \\
(0.918)\end{array}$ & $\begin{array}{l}0.034^{*} \\
(0.740)\end{array}$ \\
\hline DEM & $\begin{array}{l}-0.032^{+} \\
(0.051)\end{array}$ & $\begin{array}{l}-0.018 \\
(0.278)\end{array}$ & $\begin{array}{l}-0.014 \\
(0.398)\end{array}$ \\
\hline QDI & $\begin{array}{l}0.027^{* *} \\
(0.008)\end{array}$ & $\begin{array}{l}0.014 \\
(0.170)\end{array}$ & $\begin{array}{l}0.014 \\
(0.176)\end{array}$ \\
\hline ID & & $\begin{array}{l}0.148^{* *} \\
(0.000)\end{array}$ & \\
\hline $\mathrm{lM}_{2}$ & & & $\begin{array}{l}0.106^{*} \\
(0.048)\end{array}$ \\
\hline Spatial & & & \\
\hline Rho & $\begin{array}{l}0.129^{* *} \\
(0.000)\end{array}$ & $\begin{array}{l}0.157^{* *} \\
(0.000)\end{array}$ & $\begin{array}{l}0.157^{* *} \\
(0.000)\end{array}$ \\
\hline Lambda & $\begin{array}{l}-0.137^{* *} \\
(0.001)\end{array}$ & $\begin{array}{l}-0.155^{* *} \\
(0.000)\end{array}$ & $\begin{array}{l}-0.152^{* *} \\
(0.000)\end{array}$ \\
\hline $\begin{array}{l}\text { Variance } \\
\text { sigma2_e }\end{array}$ & $\begin{array}{l}0.0413^{* *} \\
(0.000)\end{array}$ & $\begin{array}{l}0.0419^{* *} \\
(0.000)\end{array}$ & $\begin{array}{l}0.0440^{* *} \\
(0.000)\end{array}$ \\
\hline$N$ & 200 & 200 & 200 \\
\hline
\end{tabular}

Source: BCEAO (2016), WDI (2016) \& Freedom House (2016), authors' work.

\section{Discussion of results}

\section{Financial development and economic growth}

Financial development positively affects economic growth. A 1\% improvement in financial development indicators, for example, credit to the private sector, deposits in the banking system, money supply, leads, ceteris paribus, to an increase in economic growth of $0.13 \%$, $0.15 \%$ and $0.11 \%$, respectively. Only deposits and credit to the private sector are positively and significantly correlated with long-term economic growth. In fact, an increase in the indicators of financial development of private credit and deposits of $1 \%$ would increase economic growth by $0.24 \%$ and $0.40 \%$, respectively. To have a high impact of financial development on economic growth, banks in WAEMU member countries must prioritize deposits and credit to the private sector. It should be noted that savers' deposits are generally the conduit for credit to the private sector. The goal of increasing private sector credit is to improve capital and subsequently private investment, which will ensure sustained and sustainable economic growth. The results confirm those obtained by Keho (2012), Acclassato and Eggoh (2012), Yahyoui and Rahmani (2009), Beck and Levine (2004), Beck et al. (2000) and King and Levine (1993a).

\section{Employment level and economic growth}

The results show that the level of employment negatively influences economic growth regardless of the model and financial development indicators considered. Another important result of this study is that this impact remains negative in the long-term dynamics. This conclusion, although surprising, can be explained by the existence of imperfections in the labor 
market. Employment can only grow if growth in output is greater than productivity growth. Companies tend to put their employees to work for longer hours and many of them increased their investment in equipment and became more productive, thus reducing their need for labor. The results are consistent with those obtained by Yahyoui and Rahmani (2009) and Seyfried (2007).

\section{Institutional factors and economic growth}

This section highlights the impact of democratic variables on economic development captured by economic growth. The results show a positive and significant correlation between the quality of institutions and economic growth whatever the indicators of financial development considered except the money supply. It should be noted that the democracy index does not positively affect and significantly growth, but only in the long-term relationship. Conversely, a negative effect is observed on short-term growth or in the autoregressive spatial model. This result seems surprising, but it could be explained by the fact that the establishment of institutions or democratic reforms requires sometimes more time. The negative relationship observed between democracy and economic growth in fixed effects models, autoregressive spatial model or short-term dynamics corroborate the conclusions of Helliwell and Chung (1992) and Barro (1992). The latter believes that the relationship between democracy and economic growth should be non-linear. He explains this by the fact that growth and democracy are positively correlated when the index of democracy is below its moderate level. On the contrary, the relationship becomes negative when democracy has already reached its moderate level.

\section{Other control variables and economic growth}

The effect of the trade opening rate on economic growth is positive and significant in most cases and whatever the indicators of financial development. It is proved like Kpodar (2006) that improving trade openness can promote economic growth. This effect is more pronounced in the long-term dynamic. This result converges with those obtained by Rodriguez and Rodrick (2000),Edwards (1998), Sachs and Warner (1997), Hanson and Harisson (1995), Ben - David (1993), Dollar (1992), Romer (1989) and Helpman (1988).Finally, human capital positively influences economic growth. The accumulation of human capital in the form of education favors the innovation of new financial instruments that can improve financial development. This result seems to confirm the work of defenders of the theory of endogenous growth (Krueger and Lindahl 2001, Barro and Sala-i-Martin 1995, Benhabib and Spiegel 2000, Mankiw et al 1992, Lucas, 1988). On the one hand, the estimation of the spatial autoregressive model shows that for a given country a 1\% increase in spatially-weighted average of the GDP level of its neighbors (i.e all other countries in the sample) leads to an increase of about $0.15 \%$ in its own level of GDP. This low level of diffusion of economic development is attributable to factors such as the structural constraints of the economies of the Union, the lack of dynamism of the exchanges between the communities and the countries, the development of the trade regional integration, the insufficient integration into international trade and the growing marginalization in the global economy, the regional political conflicts and the instabilities that hinder the realization of the common market. On the other hand, the estimation of error correction models capturing the heterogeneity of individuals has also allowed us to find that a shock that affects the economy will take about 2 years and 6 months to completely dissipate.

\section{CONCLUSION AND RECOMMENDATIONS}

This article analysis the impact of financial development, the level of employment and the institutions on economic growth using the classical fixed effects model methodology, with correction of Driscoll-Kraay (1998), Pooled Mean Group (PMG) of Pesaran et al. $(1995,1999)$ and spatial autoregressive models. The analysis is based on a sample of the 8 WAEMU 
countries over the period 1990-2015. To measure financial development, we have chosen the three most commonly used financial development indicators in the literature: the ratio of private sector credit to GDP, the ratio of deposits to GDP and the ratio of the money supply policy to GDP. The results suggest that financial development is positively associated with all sources of economic growth in WAEMU countries. These results are quite consistent with previous empirical studies. The policy implications of our analysis suggest that financial development should be encouraged, but it is desirable that it be as regular as possible. To enhance the impact of financial system development on growth, banks need to be encouraged to extend their financial services (at least to make deposits available) to the small scale firms, and to invest in the microfinance sector through refinancing or creation of specialized branches. Also, the implementation of policies aimed at strengthening human capital could lead ceteris paribus to improving the productivity of the workforce. This will provide an abundant and quality workforce that can support the technological innovation chain and facilitate the introduction of new financial instruments. Finally, the strengthening of democratic institutions is a guarantee to the development of the financial sector and hence to economic growth.

The specificity of this study is twofold: first, the introduction of two major methodological innovations and second the choice of the three main explicative variables concerning the financial development, the employment level and the democratic institutions. We are expecting that further studies examine other aspects of this study to contribute to the literature.

\section{BIBLIOGRAPHICAL REFERENCES}

Abdouni, A., \& Hanchane, S. (2003). "" Openness, Human Capital and Economic Growth: Theoretical Foundations and Identification of Links Using Panel Data ". Working Paper-LEST-CNRS-UMR, 6123.

Acclassato, D., \& Eggoh, J. (2013). "Banking Sector and Growth: An Analysis of Transmission Channels in UEMOA Countries". In 30th International Days of Monetary, Banking and Financial Economics, Annual Symposium of the European Research Group "Money, Banking, Finance" of the CNRS.

Anselin, L., \& Bera, A. K. (1998). "Spatial Dependence in Linear Regression Models With an Introduction to Satial Econometrics". Statistics Textbooks and Monographs, 155, 237-290.

Anselin, L., Bera, A.K., Florax, R., \& Yoon, M.J. (1996). "Simple Diagnostic Tests for Spatial Dependence". Regional Science and Urban Economics, 26 (1), 77-104.

Anselin, L., The Gallo, J., \& Jayet, H. (2008). "Spatial Panel Econometrics". In The Econometrics of Panel Data (pp. 625-660). Springer Berlin Heidelberg.

Baltagi, B. (2008). "Econometric Analysis of Panel Data". John Wiley \& Sons.

Baltagi, B.H., \& Pirotte, A. (2010). "Panel Data Inference under Spatial Dependence". Economic Modeling, 27 (6), 1368-1381.

Baltagi, B.H., Demetriades, P.O., \& Law, S.H. (2009). "Financial Development and Openness: Evidence from Panel Data". Journal of Development Economics, 89 (2), 285-296.

Barro, R. J. (1992). Human capital and economic growth. Proceedings, Federal Reserve Bank of Kansas City, 199230.

Barro, R.J., \& Sala-i-Martin, X. (1995). "Technological Diffusion, Convergence, and Growth" (No. w5151). National Bureau of Economic Research.

Beaudry, P., \& Collard, F. (2002). "Why Has the Employment-Productivity Tradeoff among Industrialized Countries Been so Strong? "(No. w8754). National Bureau of Economic Research.

Beck, T., \& Levine, R. (2004). Stock markets, banks, and growth: Panel evidence. Journal of Banking \& Finance, 28(3), 423-442.

Beck, T., Demirgüç-Kunt, A., \& Maksimovic, V. (2008). "Financing Patterns around the World: Are Small Firms Different? ". Journal of Financial Economics, 89 (3), 467-487. 
Beck, T., Levine, R., \& Loayza, N. (2000). "Finance and the Sources of Growth". Journal of Financial Economics, 58 (1), 261-300.

Ben-David, D. (1993). "Equalizing Exchange: Trade Liberalization and Income Convergence". The Quarterly Journal of Economics, 108 (3), 653-679.

Benhabib, J.,\& Spiegel, M. M. (2000). "The Role of Financial Development in Growth and Investment". Journal of Economic Growth, 5 (4), 341-360.

Berthelemy, J.C., \& Varoudakis, A. (1995). "Thresholds in Financial Development and Economic Growth". The Manchester School, 63 (S1), 70-84.

Breusch, T. S., \& Pagan, A. R. (1980). "The Lagrange Multiplier Test and its Applications to Model Specification in Econometrics". The Review of Economic Studies, 47 (1), 239-253.

Calderón, C., \& Liu, L. (2003). "The Direction of Causality between Financial Development and Economic Growth". Journal of Development Economics, 72 (1), 321-334.

Conley, T. G.,\& Ligon, E. (2002). "Economic Distance and Cross-Country Spillovers". Journal of Economic Growth, 7 (2), 157-187.

De Gregorio, J., \& Guidotti, P.E. (1995). "Financial Development and Economic Growth". World Development, 23 (3), 433-448.

Demirgüç-Kunt, A., \& Detragiache, E. (1998). "Financial Liberalization and Financial Fragility" (No. 1917). World Bank, Development Research Group and International Monetary Fund, Research Department.

Dollar, D. (1992). "LDCs, 1976-1985" "Outward-Oriented developing Economies Really Do Grow Rapidly". Economic development and cultural change, 40 (3), 523-544.

Dopke, J. (2001). "The Employment Intensity of Growth in Europe "(No. 1021). Kiel Working Paper.

Dornbusch, R., \&Reynoso, A. (1989). "Financial Factors in Economic Development"American Economic Review Papers and Proceedings, 1989, pp. 204-9.

Driscoll, J.C., \& Kraay, A.C. (1998). "Consist Covariance Matrix Estimation with Spatially Dependent Panel Data". The Review of Economics and Statistics, 80 (4), 549-560.

Easterly, W., \& Levine, R. (1998). "Troubles with the Neighbors: Africa's Problem, Africa's Opportunity". Journal of African Economies, 7 (1), 120-142.

Eberhardt, M. (2012). "Estimating Panel Time-Series Models with Heterogeneous Slopes". Stata Journal, 12 (1), 61.

Edwards, S. (1998). "Openness, Productivity and Growth: What Do we Really Know? ". The Economic Journal, 108 (447), 383-398.

Elhorst, J. P. (2001). "Or Spatially Lagged Dependent Variable ". University of Groningen.

Elhorst, J. P. (2003). "Specification and Estimation of Spatial Panel Data Models". International Regional Science Review, 26 (3), 244-268.

Elhorst, J. P. (2014). "Spatial Panel Data Models". In Spatial Econometrics (pp. 37-93). Springer Berlin Heidelberg.

Ertur, C., \& Koch, W. (2007). "Growth, Technological Interdependence and Spatial Externalities: Theory and Evidence". Journal of Applied Econometrics, 22 (6), 1033-1062.

Ertur, C., \& Thiaw, K. (2005). "Croissance, Capital Humain et Interactions Spatiales : Une Etude Econométrique“. Document de Travail du LEG, Université de Bourgogne, (2005-04).

Fingleton, B. (1999). "Estimates of Time to Economic Convergence: an Analysis of Regions of the European Union". International regional science review, 22 (1), 5-34.

Fosu, A. K. (2013). Growth of African economies: productivity, policy syndromes and the importance of institutions. Journal of African Economies, 22(4), 523-551.

Frankel, J.A., \& Romer, D. (1996). "Trade and Growth: An Empirical Investigation" (No. w5476). National Bureau of Economic Research.

Frankel, J.A., Romer, D., \& Cyrus, T. (1996). "Trade and Growth in East Asian Countries: Cause and Effect?" (No. W 5732). National Bureau of Economic Research.

Hanson, G.H., \& Harrison, A. (1995). "Trade, Technology, and Wage Inequality". (No. w5110). National Bureau of Economic Research. 
Ayivodji, F., Hounsou, R., \& Tago, E. (2019). Analysis of the Relationship between Financial Development, Employment and Institutions on Economic Growth in WAEMU Countries. Archives of Business Research, 7(12), 267-291.

Hausman, J. A. (1978). "Specification Tests in Econometrics. Econometrica": Journal of the Econometric Society, 1251-1271.

Helliwell, J. F., \& Chung, A. (1992). "Convergence and Growth Linkages between North and South". (No. w3948). National Bureau of Economic Research.

Helpman, E. (1988). "Growth, Technological Progress, and Trade". NBER Working Paper, 2592.

Hoechle, D. (2007). "Robust Standard Errors for Panel Regressions with Cross-Sectional Dependence". Stata Journal, 7 (3), 281.

Hsiao, C. (1986). "Analysis of Panel Data". Econometric Society Monograph No. 11.

Hsiao, C. (2014). "Analysis of Panel Data". (No. 54). Cambridge university press.

Hsiao, C., Pesaran, M.H., \& Tahmiscioglu, A.K. (1999). "Bayes Estimation of Short-Run Coefficients in Dynamic Panel Data Models".Chapter 11 in Hsiao C., Lahiri K.,Lee L. F., and Pesaran M. H., eds., Analysis of Panels and Limited Dependent Variable Models (Cambridge University Press, Cambridge), 268-296.

Hurlin, C., \& Mignon, V. (2005). "Une Synthèse des Tests de Racine Unitaire sur Données de Panel“. Economie \& prévision, (3), 253-294.,

Islam, I., \& Nazara, S. (2000). "Estimating Employment Elasticiy for the Indonesian Economy". Jakarta, Indonesia: International Labor Office.

Islam, R. (2004) 'The Nexus of Economic Growth, Employment and Poverty Reduction: An Empirical Analysis', International Labour Office, Issues in Employment and Poverty.

Kao, C., \& Chiang, M.H. (2000). "On the Estimation and Inference of a Cointegrated Regression in Panel Data. In Nonstationary Panels, panel Cointegration, and Dynamic Panels "(pp. 179-222). Emerald Group Publishing Limited.

Kapsos, S. (2005). "Estimating Growth Requirements for Reducing Poverty: Can the World Halve Working Poverty by 2015? ". International Labor Office.

Keho, Y., (2012), "The Role of Institutional Factors in the Economic Development of WAEMU Countries". BCEAO Economic and Monetary Review $N^{\circ} 12$ December.

King, R. G., \& Levine, R. (1993a). "Financial Indicators and Growth in a Cross Section of Countries", Working Paper no. 819 (The World Bank, Washington, DC).

King, R. G., \& Levine, R. (1993b). "Finance and Growth: Schumpeter Might Be Right". The QuarterlyJjournal of Economics, 108 (3), 717-737.

Kiviet, J. F. (1995). "On Bias, Inconsistency, and Efficiency of Various Estimators in Dynamic Panel Data Models". Journal of Econometrics, 68 (1), 53-78.

Kormendi, R. C., \& Meguire, P. G. (1985). Macroeconomic determinants of growth: cross-country evidence. Journal of Monetary economics, 16(2), 141-163.

Kpodar, K.R (2006), "Financial Development and the Problem of Reducing Poverty", CERDI.

Kruger, A. B., \& Lindahl, M. (2001). "Education for Growth: Why and for Whom?" Journal of Economic Literature, $39(4), 1101-1136$.

Landesmann, M. and Pagano U. (1994), "Institutions and Economic Change".Structural Change and Economic Dynamics, 5 (2), 199-203.

Law, S.H. \& Demetriades, P. (2004, September). "Capital Inflows, Trade Openness and Financial Development in Developing Countries". In Money Macro and Finance Research Group Conference. London (pp. 6-8).

Law, S.H., \& Azman-Saini, W. N. W. (2008). "The Quality of Institutions and Financial Development".MPRA Paper No. 12107, 1-19. University Library of Munich.

Law, S.H., \& Habibullah, M.S. (2009). "The Determinants of Financial Development: Institutions, Openness and Financial Liberalization". South African Journal of Economics, 77 (1), 45-58.

Le Gallo, J., Baumont, C., Dall'erba, S., \& Ertur, C. (2005). "On the Property of Diffusion in the Spatial Error Model". Applied Economics Letters, 12 (9), 533-536.

Levine, R., \& Renelt, D. (1992). "A sensitivity analysis of cross-country growth regressions". The American economic review, 942-963. 
Levine, R., Loayza, N.,\& Beck, T. (2000). "Financial Intermediation and Growth: Causality and Causes". Journal of Monetary Economics, 46 (1), 31-77.

Lucas, R., (1988). "On the Mechanics of Economic Development", Journal of Monetary Econometric 22. July 342.

Mankiw, N.G., Romer, D., \& Weil, D.N. (1992). "A Contribution to the Empirics of Economic Growth". The Quarterly Journal of Economics, 107 (2), 407-437.

McKinnon, R.I. (1973). "Money and Capital Economic Development". Brookings Institution, Washington, DC.

Moreno, R., \& Trehan, B. (1997). "Location and the Growth of Nations". Journal of Economic Growth, 2 (4), 399-418.

Mourre, G. (2004). "Did the Pattern of Aggregate Employment Growth Change in the Euro Area in the Late 1990s?

"; European Central Bank. Discussion paper 358.

Nelson, R.R., \& Sampat, B.N. (2001). "Making Sense of Institutions as a Factor Shaping Economic Performance". Revista de Economía Institucional, 3 (5), 17-51.

Neusser, K., \& Kugler, M. (1998). "Manufacturing Growth and Financial Development: Evidence from OECD Countries". The Review of Economics and Statistics, 80 (4), 638-646.

North, D.C. (1990). "Institutions, Institutional Change and Economic Performance". Cambridge University Press.

Odedokun, M. O. (1996). "Alternative Econometric Approaches for the Analysis of the Role of the Financial Sector in Economic Growth: Time-Series Evidence from LDCs". Journal of Development Economics, 50 (1), 119-146.

Padalino, S., \& Vivarelli, M. (1997). "The Employment Intensity of Economic Growth in the G-7 Countries". Int'l Lab. Rev., 136, 191.

Pagano, M. (1993). "Financial Markets and Growth: An Overview". European Economic review, 37 (2-3), 613-622.

Patrick, H. T. (1966). "Financial Development and Economic Growth in Underdeveloped Countries". Economic Development and Cultural Change, 14 (2), 174-189.

Pedroni, P. (1999). "Critical Values for Cointegration Tests in Heterogeneous Panels with Multiple Regressors". Oxford Bulletin of Economics and Statistics, 61 (S1), 653-670.

Pedroni, P. (2001). Fully Modified OLS for Heterogeneous Cointegrated Panels in Nonstationary Panels, Panel Cointegration, and Dynamic Panels ". (pp. 93-130). Emerald Group Publishing Limited.

Pedroni, P. (2004). "Panel Cointegration: Asymptotic and Finite Sample Properties of Pooled Time Series Tests with an Application to the PPP Hypothesis“. Econometric Theory, 20(3), 597-625.

Pehkonen, J. (2000), Employment, unemployment and output growth in booms and recessions: time series evidence from Finland, 1970-1996, in Applied Economics, 32, pp. 885-900.

Perugini, C. (2009). "Employment Intensity of Growth in Italy A Note Using Regional Data". Regional and Sectoral Economic Studies, 9(1), 59-105.

Pesaran, M. H. (2004). “General Diagnostic Tests for Cross Section Dependence in Panels“.Cambridge Working Papers in Economics $N^{\circ} 0435$, Faculty of Economics, University of Cambridge.

Pesaran, M. H., \& Smith, R. (1995). "Estimating Long-Run Relationships from Dynamic Heterogeneous Panels“. Journal of Econometrics, 68(1), 79-113.

Pesaran, M. H., Shin, Y., \& Smith, R. P. (1999). "Pooled Mean Group Estimation of Dynamic Heterogeneous Panels“. Journal of the American Statistical Association, 94(446), 621-634.

Pesaran, M. H., Ullah, A., \& Yamagata, T. (2008). "A Bias-Adjusted LM Test of Error Cross-Section Independence“. The Econometrics Journal, 11(1), 105-1"27.

Piacentini, P.,\& Pini, P. (2000). "Growth and Employment. The Employment Impact of Innovation: Evidence and Policy“. London: Routledge, pp. 44-76.

Pirotte, A. (2011). "Économétrie des Données de Panel: Théorie et Applications“. Economica.

Rebelo, S. (1991). Long-run policy analysis and long-run growth. Journal of political Economy, 99(3), 500-521.

Robinson, J. (1952). "The Generalization of the General Theory“. In: The Rate of Interest and Other Essays (MacMillan, London).

Rodriguez, F., \& Rodrik, D. (2000). “Trade Policy and Economic Growth: a Skeptic's Guide to the Cross-National Evidence“. NBER Macroeconomics Annual, 15, 261-325. 
Romer, P, 1989, "Capital Accumulation and the Theory of Long-Run Growth". In: R. Barro. ed. Modern Business Cycle Theory (Harvard University Press, Cambridge, MA).

Roubini, N. and Sala-y-Martin, X., (1992). "A Growth Model of Inflation, Tax Evasion. and Financial Repression ", Working Paper no. 4062 (NBER, Cambridge, MA) May.

Rousseau, P.L., \& Wachtel, P. (2011). "What is Happening to the Impact of Financial Deepening on Economic Growth?" Economic Inquiry, 49 (1), 276-288.

Sachs, J.D., \& Warner, A.M. (1997). "Sources of Slow Growth in African Economies". Journal of African Economies, 6 (3), 335-376.

Savvides, A. (1995). "Economic Growth in Africa". World Development, 23 (3), 449-458.

Sevestre, P. (2002). "Econometrics of Panel Data". (pp 109-152). Paris: Dunod.

Seyfried, W. (2007). "Cross-Country Analysis of the Employment Intensity of Economic Growth". Southwest Business \& Economics Journal, 16.

Shaw, E. S. (1973). "Financial Deepening in Economic Development".Oxford University Press.

Spears, A. (1992). "The Role of Financial Intermediation in Economic Growth in Sub-Saharan Africa". Canadian Journal of Development Studies, 13 (3), 361-380.

Suryadarma, D., Suryahadi, A., \& Sumarto, S. (2007). "Reducing Unemployment in Indonesia: Results from a Growth-Employment Elasticity Model". SMERU Research Institute.

Venet, B., \& Raffinot, M. (1998). "Financial Deepening, Financial Liberalization and Growth: the Case of the West African Economic and Monetary Union (UEMOA)". 15th International Days of Monetary and Banking Economics.

Wooldridge, J. M. (2002). "Econometric Analysis of Cross Section and Data Panel". The MIT Press 0, 5 (1), 5.

Wurgler, J. (2000). "Financial Markets and the Allocation of Capital". Journal of Financial Economics, 58 (1), 187 214.

Yahyaoui, A., \&Rahmani, A. (2009). "Financial Development and Economic Growth: Role of Institutional Quality". Panoeconomicus, 56 (3), 327-357.

Yu, J., De Jong, R., \& Lee, L. F. (2008). "Quasi-Maximum Likelihood Estimators for Spatial Dynamic Data Panel with Fixed Effects Both N and T Are Large". Journal of Econometrics, 146 (1), 118-13. 


\section{APPENDICES}

Table 5: Hsiao Homogeneity Test Results (1986)

\begin{tabular}{|l|c|}
\hline Statistics & P-value \\
\hline F1=16.58 & 0.00 \\
\hline F2 $=5.59$ & 0.08 \\
\hline F3 $=\mathbf{4 7 . 8 0}$ & 0.00 \\
\hline
\end{tabular}

Source: BCEAO (2016), WDI (2016) \& Freedom House (2016), authors' work.

Table 6: Model Specification Test Results

\begin{tabular}{lll}
\hline Tests & Statistics & P-value \\
\hline Hausman (1978) & 150.78 & 0.00 \\
\hline Wooldrige (2002) & 10419.11 & 0.00 \\
\hline Hoechle (2007) & 1522.30 & 0.00 \\
\hline Cluster- Robust Hausman (with bootstrap, 200 simulations) & 18.6 & 0.03 \\
\hline
\end{tabular}

Source: BCEAO (2016), WDI (2016) \& Freedom House (2016), authors' work.

Table 7: Diagnotics of the standard fixed effects model before Driscoll-Kraay correction (1998)

\begin{tabular}{lllll}
\hline Diagnostics & & & & \\
\hline \multirow{4}{*}{ Autocorrelation } & Tests & Statistics & P-value & Decision \\
& Baltagi-Wu & 0.69 & & \\
& $\begin{array}{l}\text { Durbin-Waston } \\
\text { Wooldrige }\end{array}$ & 0.82 & & Autocorrelation \\
\hline \multirow{4}{*}{ Heteroscedasticity } & & & & \\
& Breusch-Pagan & 40.76 & 0.00 & Heteroscedasticity \\
& & & & \\
\hline \multirow{5}{*}{ Normality } & Jarque-Bera & 0.41 & 0.81 & \\
& Shapiro-Wilk & 0.99 & 0.90 & Normality \\
& Shapiro-Francia & 0.99 & 0.82 &
\end{tabular}

Source: BCEAO (2016), WDI (2016) \& Freedom House (2016), authors' work

Table 8: Variable Dependence Test Results

\begin{tabular}{lllll}
\hline Variable & CD-test & P-value & corr & abs(corr) \\
\hline lGDP & 26.18 & 0.00 & 0.970 & 0.970 \\
lC & 15.62 & 0.00 & 0.635 & 0.254 \\
lD & 4.56 & 0.00 & 0.169 & 0.338 \\
$\mathrm{lM}_{2}$ & 4.75 & 0.00 & 0.176 & 0.396 \\
lPOP & 15.41 & 0.00 & 0.571 & 0.585 \\
InEDU & 13.23 & 0.00 & 0.355 & 0.461 \\
ITRA & 0.75 & 0.00 & 0.288 & 0.273 \\
DEM & 18.32 & 0.00 & 0.323 & 0.510 \\
QDI & 12.30 & 0.00 & 0.456 & 0.456 \\
\hline
\end{tabular}

Source: BCEAO (2016), WDI (2016) \& Freedom House (2016), authors' work 
Table 9: Results of the panel dependence test

Dependence test

\begin{tabular}{llll}
\hline & Statistics & P-value & Decision \\
\cline { 2 - 4 } Breusch-Pagan (1980) & 55.7 & 0.00 & \\
Pesaran (2004)-CDtest & 4.28 & 0.00 & Inter-individual dependence \\
Pesaran et al. (2008) & 5.55 & 0.00 & \\
\hline
\end{tabular}

Source: BCEAO (2016), WDI (2016) \& Freedom House (2016), authors' work.

Table 10: Results of First and Second Generation Unit Root Tests

\begin{tabular}{|c|c|c|c|c|c|c|}
\hline \multirow[b]{3}{*}{ Variables } & \multicolumn{4}{|c|}{ First Generation } & \multirow{2}{*}{\multicolumn{2}{|c|}{$\begin{array}{l}\text { Second Generation } \\
\text { Pesaran (2007) }\end{array}$}} \\
\hline & \multicolumn{2}{|c|}{ Breitung (200) } & \multicolumn{2}{|c|}{ Maddala and Wu (1999) } & & \\
\hline & Level & Diff & Level & Diff & Level & Diff \\
\hline & p-value & p-value & $\mathrm{p}$-value & $\mathrm{p}$-value & $\mathrm{p}$-value & $\mathrm{p}$-value \\
\hline lGDP & 0.42 & 0.00 & 0.30 & 0.01 & 0.96 & 0.00 \\
\hline $\mathrm{lC}$ & 0.06 & 0.00 & 0.42 & 0.00 & 0.74 & 0.00 \\
\hline lD & 0.24 & 0.00 & 0.54 & 0.00 & 0.11 & 0.00 \\
\hline $\mathrm{lM}_{2}$ & 0.13 & 0.00 & 0.64 & 0.00 & 0.42 & 0.00 \\
\hline IPOP & 0.25 & 0.00 & 0.06 & 0.00 & 0.93 & 0.00 \\
\hline lEDU & 0.63 & 0.00 & 0.34 & 0.00 & 0.92 & 0.00 \\
\hline ITRA & 0.23 & 0.00 & 0.86 & 0.00 & 0.19 & 0.00 \\
\hline DEM & 0.23 & 0.00 & 0.57 & 0.00 & 0.99 & 0.00 \\
\hline QDI & 0.10 & 0.02 & 0.00 & 0.00 & 0.74 & 0.02 \\
\hline
\end{tabular}

Source: BCEAO (2016), WDI (2016) \& Freedom House (2016), authors' work.

Notes: Level = indicates the level stationarity test; Diff = indicates the stationarity test in first difference.

Table 11: Results of the cointegration test on panel data

\begin{tabular}{lll}
\hline Stats.Test & Panel & Group \\
\hline $\mathrm{V}$ & -1.39 & - \\
Rho & 4.55 & 3.66 \\
$\mathrm{~T}$ & -2.65 & -2.60 \\
Adf & -4.61 & -4.87 \\
\hline
\end{tabular}


Source: BCEAO (2016), WDI (2016) \& Freedom House (2016), authors' work.

Table 12: Comparison Test Results for SAC and SEM Models

\begin{tabular}{|c|c|c|c|c|c|}
\hline Model & Obs & Likelihood(model) & df & AIC & BIC \\
\hline \multicolumn{6}{|l|}{ Private credit : $\mathrm{C}$} \\
\hline Spatial Autoregressive Model (SAC) & 200 & 152.85 & 9 & -287.6915 & -258.01 \\
\hline Spatial Error Model (SEM) & 200 & 120.44 & 8 & -224.87 & -198.49 \\
\hline \multicolumn{6}{|l|}{ Depos it : D } \\
\hline Spatial Autoregressive Model (SAC) & 200 & 161.66 & 9 & -305.31 & -275.63 \\
\hline Spatial Error Model (SEM) & 200 & 125.84 & 8 & -235.67 & -209.28 \\
\hline \multicolumn{6}{|l|}{ Money s upply : M2 } \\
\hline Spatial A utoregressive Model (SAC) & 200 & 183.34 & 9 & -348.67 & -318.98 \\
\hline Spatial Error Model (SEM) & 200 & 145.61 & 8 & -275.22 & -248.83 \\
\hline
\end{tabular}

Source: BCEAO (2016), WDI (2016) \& Freedom House (2016), authors' work.

Table 13: Breakdown of active credit institutions by country

\begin{tabular}{|c|c|c|c|c|c|c|c|c|}
\hline \multirow[t]{2}{*}{ Country } & \multicolumn{3}{|c|}{$\begin{array}{l}\text { Number of } \\
\text { institutions }\end{array}$} & \multirow{2}{*}{$\begin{array}{c}\text { Total balance } \\
\text { sheet(millions FCFA) }\end{array}$} & \multirow{2}{*}{$\begin{array}{c}\text { Market } \\
\text { share }(\%)^{(1)}\end{array}$} & \multirow[t]{2}{*}{$\mathrm{BB}^{(2)}$} & \multirow[t]{2}{*}{$\operatorname{ATM}^{(3)}$} & \multirow{2}{*}{$\begin{array}{l}\text { Number of bank } \\
\text { accounts }\end{array}$} \\
\hline & Banks & FI & Total & & & & & \\
\hline Benin & 13 & - & 13 & $3,324,419$ & 11.8 & 205 & 277 & $1,056,113$ \\
\hline $\begin{array}{l}\text { Burkina } \\
\text { Faso }\end{array}$ & 13 & 4 & 17 & $3,768,914$ & 13.4 & 280 & 341 & $1,358,761$ \\
\hline $\begin{array}{l}\text { Ivory } \\
\text { Coast }\end{array}$ & 24 & 2 & 26 & $8,294,479$ & 29.4 & 635 & 896 & $2,608,537$ \\
\hline $\begin{array}{l}\text { Guinea- } \\
\text { Bissau }\end{array}$ & 4 & - & 4 & 195,225 & 0.7 & 27 & 42 & 97,689 \\
\hline Mali & 14 & 3 & 17 & $3,840,616$ & 13.6 & 533 & 405 & $1,310,529$ \\
\hline Niger & 11 & 1 & 12 & $1,286,632$ & 4.5 & 148 & 145 & 481,715 \\
\hline Senegal & 23 & 2 & 25 & $5,463,295$ & 19.3 & 392 & 454 & $1,391,205$ \\
\hline Togo & 13 & 2 & 15 & $2,059,304$ & 7.3 & 210 & 239 & $1,069,666$ \\
\hline waemu & 115 & 14 & 129 & $28,214,884$ & 100 & 2,430 & 2,799 & $9,374,215$ \\
\hline
\end{tabular}

Source: BCEAO (2016), WDI (2016) \& Freedom House (2016), authors' work.

Notes: Annual Report of the WAMU Banking Commission, FI = Financial Institution, (1): compared to the total WAMU balance sheet; (2) Agencies, offices and points of sale; (3) ATM= Automatic Teller Machine. 